\title{
Determination and Fractionation of Barium in Brazil Nuts
}

\author{
Alexandra M. Gonçalves, ${ }^{a}$ Kelly G. Fernandes, ${ }^{b}$ Luiz A. Ramos, $^{c}$ Éder T. G. Cavalheiro ${ }^{c}$ \\ and Joaquim A. Nóbrega*,a
}

${ }^{a}$ Departamento de Química, Universidade Federal de São Carlos, P.O Box 676, 13560-970 São Carlos-SP, Brazil

${ }^{b}$ Departamento de Química, Universidade Federal do Pará, Belém-PA, Brazil

'Instituto de Química de São Carlos, Universidade de São Paulo, São Carlos-SP, Brazil

\begin{abstract}
Diversas estratégias para preparo de amostra, determinação e fracionamento, tais como espectrometria de absorção atômica com atomização eletrotérmica em forno de grafite (GF AAS) e espectrometria de emissão óptica com plasma acoplado indutivamente com configuração axial (ICP OES), foram empregadas para o fracionamento de bário em Castanha-do-Pará. Esse alimento é amplamente apreciado tanto pelo valor nutricional, quanto pelo sabor agradável. A análise química de Castanha-do-Pará não é trivial devido à matriz complexa. O fracionamento de bário em Castanha-do-Pará foi estudado devido à toxicidade desse elemento e a correlação entre a forma química e a absorção. Os teores totais de bário nas amostras de Castanha-do-Pará variaram entre 860 e $2084 \mathrm{mg} \mathrm{kg}^{-1}$. Extrações sequenciais foram feitas com base na solubilidade em diferentes meios e composição química envolvendo lipídios, proteínas e compostos de baixa massa molecular (LMW). Teores mais elevados de bário foram determinados nas frações LMW e insolúvel em água que variaram entre 778-1606 e 551-1520 $\mathrm{mg} \mathrm{kg}^{-1}$, respectivamente. Esses resultados indicaram a indisponibilidade de bário presente nesse alimento ao organismo humano. Baseando-se nos teores de bário e enxofre nas diferentes frações e em cálculos estequiométricos para as possíveis reações envolvidas pode-se inferir que bário se encontra principalmente na forma de $\mathrm{BaSO}_{4}$. Experimentos termogravimétricos também confirmaram essa suposição.
\end{abstract}

Several sample preparation strategies were employed for determination and fractionation of barium in Brazil nuts using measurements by graphite furnace atomic absorption spectrometry (GF AAS) and inductively coupled plasma optical emission spectrometry with axial view (ICP OES). This food is widely consumed because of its nutritional value and good taste. The chemical analysis of Brazil nuts is not trivial due to their complex matrix. The fractionation of barium in Brazil nuts was studied owing to the toxicity of this element and the strong correlation between chemical form and absorption. Total concentrations of barium varied from 860 to $2084 \mathrm{mg} \mathrm{kg}^{-1}$. Sequential extractions were performed based on solubility in different media and also according to lipids, proteins and low molecular weight fractions (LMW). The greatest contents of barium were determined in the LMW and in the water insoluble fractions with concentrations in the range 778 to 1606 and 551 to $1520 \mathrm{mg} \mathrm{kg}^{-1}$, respectively. Based on these results it can be inferred that $\mathrm{Ba}$ is not absorbed when Brazil nuts are ingested. Considering both the contents of barium and sulfur in different fractions and stoichiometric calculations it was also possible to assume that barium occurs mainly in the $\mathrm{BaSO}_{4}$ form. The presence of this chemical form was also confirmed by thermogravimetric measurements.

Keywords: Brazil nuts, barium, fractionation, nutritional availability

\section{Introduction}

The understanding of the role of essential and toxic elements in foods is of vital importance as well as their

*e-mail: djan@ufscar.br

This research was based on a suggestion presented by the late Prof. Eduardo F. A. Neves. chemical form. Studies have shown that the bioavailability of elements to humans depend on their chemical form. ${ }^{1}$

In this context, chemical speciation is important for identification of the chemical forms of elements in foods, such as the oxidation states and formation of complexes. ${ }^{2}$ Therefore, the physiological effect of an element cannot be associated exclusively with its total concentration. 
Additionally, as a first approach, a fractionation procedure can be applied to identify different classes of an element in a food. The fractionation procedure may involve properties of the chemical species, such as size, solubility, affinity, hydrophobicity, and charge. Both strategies are critically dependent on sample preparation. Frequently, the sample matrix interferes and analytes eventually present in trace levels may be present in unstable forms. ${ }^{3}$ The sample preparation step may involve digestion, pre-concentration and removal of interferents, ${ }^{4}$ followed by determination using spectroanalytical methods. ${ }^{5-6}$

Analysis of Brazil nuts (Bertholletia excelsa H.B.K., pertaining to the Lecythidaceae family) is not trivial owing to their complex chemical composition, typically containing $50-70 \%$ of lipids, $10-20 \%$ of proteins and $10-20 \%$ of carbohydrates. Brazil nuts are a rich source of nutrients, vitamins, minerals and fibers. ${ }^{7}$ It is a native plant of the Amazon region. The tree produces tasty and highly nourishing almonds and their wood is also valuable. Its cultivation and extraction are important considering the economic conditions of the region, being intensely consumed by native population and abroad. The Brazil nuts tree can reach up to $50 \mathrm{~m}$ of height and $2 \mathrm{~m}$ of diameter and its fruit is called ouriço, a capsule of spherical format with a hard shell that contains around 15 to 24 seeds. ${ }^{8}$ Each almond has a length of 3 to $5 \mathrm{~cm}$ with a brown film on the surface. This tree also occurs in Venezuela, Colombia, Peru, Bolivia and Guianas. ${ }^{9-10}$

This food promotes diverse benefits to the human health owing to its anticarcinogenic properties. Its action against the formation of tumors has been investigated. Ip and Lisk demonstrated that the inclusion of this food in diets for rats with induced cancer contributed for a reduction of the tumors in up to $72.7 \% .^{11}$ This effect seems to be related to the high contents of selenium, mainly present in the form of Se-methionine and also associated with compounds of low molecular weight. ${ }^{7}$

Brazil nuts are one of the richest foods in proteins and amino acids containing sulfur, particularly methionine and cysteine (380 and $130 \mathrm{mg} \mathrm{g}^{-1}$, corresponding to 18 and $8 \%$, respectively), contributing for their high nutritional value. ${ }^{12-14}$ Brazil nuts usually contain high levels of selenium and there is a vast literature about this element. A study developed for Kannamkumarath et al. ${ }^{15}$ evidenced that the main protein specie containing selenium is the Semethionine, which is a bioavailable form.

The presence of barium in high levels in Brazil nuts is surprising and concentrations can reach values as high as $4 \mathrm{mg} \mathrm{g}^{-1} \cdot{ }^{16}$ Barium does not exist in nature in its elemental form, but occurs as a divalent cation in combination with others elements. It is not considered essential and depending on their chemical form can be toxic, mainly when present in soluble salts. ${ }^{17-18}$ Therefore, it is important to investigate the chemical forms that barium occurs in Brazil nuts. The occurrence of this element in Brazil nuts may derive from the presence of hollandite ore $\left(\mathrm{Ba}_{2} \mathrm{Mn}_{8} \mathrm{O}_{16}\right)$ in soils. ${ }^{19}$

Studies on the deposition of barium in the skeleton of rats fed with Brazil nuts indicate that barium can occur in this food in a soluble form, similar to barium chloride. The soluble salts of barium are rapidly absorbed by the bloodstream. This metal can be deposited in bones and can be easily excreted by feces. ${ }^{20}$

These chemical aspects were tragically observed in the Celobar ${ }^{\circledR}$ case happened in Brazil in 2003. ${ }^{21}$ Patients performing radiological exams must ingest a medicine based on barium sulfate to improve contrast in radiographies. Apparently, the synthesis of this salt was carried out using barium carbonate as reagent, which is insoluble in water but easily dissolved in diluted acid. Thus, the incomplete conversion of the raw material resulted in the bioavailability of barium in the body causing lethal toxic effects. ${ }^{21}$

The accumulation of barium and radium is caused by the unique ability of the Brazil nuts tree to absorb these metals, as compared to others plants. Possibly it is a special mechanism involving the formation of organic complexes that increase the mobility of alkaline earth ions, in particular barium and radium, favoring their movement and redistribution during development of nuts. ${ }^{22}$

The developed study was focused on the determination and fractionation of barium in Brazil nuts. The goal was to establish which classes of compounds contain barium and infer about possible implications to human health. The hypothesis of this work is that the chemical species of barium in the Brazil nuts would be barium selenate or barium sulfate based on the high concentrations of selenium and sulfur contained in Brazil nuts. This hypothesis is consistent with the non-toxicity of this food.

\section{Experimental}

\section{Instrumentation}

The determinations of total concentrations of $\mathrm{Ba}$ and Se were carried out using a Varian Spectra AA 800 atomic absorption spectrometer (Mulgrave, Victoria, Australia) equipped with a transverse Zeeman effect background corrector and a longitudinal-heated graphite furnace atomizer. Barium was measured at $553.6 \mathrm{~nm}$ and Se at $196.0 \mathrm{~nm}$. All measurements were based on integrated absorbance. Barium hollow cathode lamp and Se hollow cathode ultralamp were operated applying electric currents of 20 and $15 \mathrm{~mA}$, respectively. Argon was used as purge 
gas. The temperature programs used for determination of $\mathrm{Ba}$ and $\mathrm{Se}$ are shown in Table 1.

A Vista AX axial view simultaneous inductively coupled plasma optical emission spectrometer (Varian), equipped with a CCD detector was used for determining $\mathrm{Ba}, \mathrm{S}, \mathrm{Se}$, and $\mathrm{P}$ in acid digests and in different fractions. The instrumental operating conditions are shown in Table 2. All measurements were performed using an argon gas plasma.

Table 1. GF AAS temperature program for determination of total barium and selenium

\begin{tabular}{lccc}
\hline Step & $\begin{array}{c}\text { Temperature } \\
\left({ }^{\circ} \mathrm{C}\right)\end{array}$ & $\begin{array}{c}\text { Ramp, Hold } \\
\left({ }^{\circ} \mathrm{C} \mathrm{s}^{-1}, \mathrm{~s}\right)\end{array}$ & $\begin{array}{c}\text { Ar flow rate } \\
\left(\mathrm{L} \mathrm{min}^{-1}\right)\end{array}$ \\
\hline 1 & 90 & 5,15 & 3.0 \\
2 & 120 & Ba: 10,$20 ;$ Se: 5,25 & 3.0 \\
3 & Ba: $1600 ;$ Se: 1200 & Ba: 5,$10 ;$ Se: 3,5 & 3.0 \\
4 & Ba: $2600 ;$ Se: 2200 & Ba: 2,$3 ;$ Se: 1,5 & 0 \\
5 & Ba: $2700 ;$ Se: 2600 & 1,3 & 3.0 \\
\hline
\end{tabular}

Table 2. ICP OES AXIAL operational parameters

\begin{tabular}{ll}
\hline Parameter & Instrumental Condition \\
\hline Applied power & $1.3 \mathrm{~kW}$ \\
Plasma gas flow rate & $15.0 \mathrm{~L} \mathrm{~min}^{-1}$ \\
Auxiliary gas flow rate & $1.5 \mathrm{~L} \mathrm{~min}^{-1}$ \\
Nebulizer gas flow rate & $0.9 \mathrm{~L} \mathrm{~min}^{-1}$ \\
Sample flow rate & $0.9 \mathrm{~mL} \mathrm{~min}^{-1}$ \\
Nebulizer and spray chamber type & V-groove and Sturman-Masters \\
$\begin{array}{l}\text { Element / Analytical wavelengths } \\
\text { (nm) }\end{array}$ & Ba II 233.527; Ba II 455.403; \\
& P I 213.618; S I 180.669; \\
\hline
\end{tabular}

A thermogravimetric simultaneous module TG/DTA SDT Q-600 (TA Instruments, New Castle, DE, USA) controlled by the software Thermal Advantage (version 1.4) was used for analysis of residues of fractionation based on solubility.

The acid digestion of Brazil nuts samples were performed in a microwave oven Ethos 1600 (Milestone, Sorisole, Italy) equipped with 8 closed vessels made of perfluoralkoxy Teflon ${ }^{\circledast}$ (PFA). The heating program used is shown in Table 3. A sub-boiling still (subPUR, Milestone) was used for further purification of concentrated nitric acid. A cryogenic mill SPEX CertPrep model 6750 (Metuchen, NJ, USA) was used for grinding Brazil nuts without shells. An ultrasonic bath model USC 1400 (Unique, São Paulo, SP, Brazil) was used for sonication when indicated. Centrifugation was performed using a Hermle centrifuge model Z 200 A (Wehingen, Germany).
Table 3. Heating program for microwave-assisted acid digestion

\begin{tabular}{lccc}
\hline Step & $\begin{array}{c}\text { Time } \\
(\mathrm{min})\end{array}$ & $\begin{array}{c}\text { Power } \\
(\mathrm{W})\end{array}$ & $\begin{array}{c}\text { Temperature } \\
\left({ }^{\circ} \mathrm{C}\right)\end{array}$ \\
\hline 1 & 3.0 & 300 & 120 \\
2 & 1.0 & 0 & 120 \\
3 & 6.0 & 500 & 210 \\
4 & 5.0 & 650 & 240 \\
$5 *$ & 5.0 & 0 & 0 \\
\hline * ventilation & & &
\end{tabular}

\section{Reagents, solutions and samples}

All solutions were prepared by using analytical grade reagents, ultra pure water obtained in a Milli-Q water purification system (Millipore, Bedford, MA, USA) and nitric acid (Merck, Darmstadt, Germany) distilled in quartz sub-boiling stills.

Reference solutions were prepared by suitable dilution of the stock solutions containing $1000 \mathrm{mg} \mathrm{L}^{-1}$ of each element, i.e. Ba, P, S, and Se (Spex CertPrep) in $0.014 \mathrm{~mol} \mathrm{~L}^{-1} \mathrm{HNO}_{3}$.

The following gases and reagents were also used: argon and nitrogen gases (99.999\% purity, White Martins, SP, Brazil), hydrogen peroxide (Mallinckrodt, Xalostoc, Mexico), perchloric acid, sodium hydroxide, phosphoric acid, acetone, sodium bicarbonate and a mixture of chloroform-methanol 2:1 v/v (Merck). All solutions and samples were stored in decontaminated polyethylene bottles and kept under refrigeration.

All experimental work was made for 5 samples. The Brazil nuts were bought with and without shells in Maranhão (sample 1), São Paulo (sample 2) and Pará (samples 3, 4 and 5). The three samples acquired in the Pará State had different forms: with shells (sample 3), with shells inside of the ouriço (sample 4), and without shells (sample 5).

\section{Procedures}

Several procedures for sample preparation were used for the determination of total concentrations and fractions obtained after sequential extractions. Lipids, low molecular weight (LMW) and proteins fractions were determined using sequential extractions according to Kannamkumarath et al. ${ }^{7}$

Samples of Brazil nuts without shells were ground in a cryogenic mill using an immersed container in liquid nitrogen. A two step program was applied: step $i$ - prefreezing: 4 min, step $i i$ - milling: 2 min intercalated by cycles of freezing of $2 \mathrm{~min}$. 


\section{Determination of total concentrations}

A microwave-assisted acid digestion was performed applying the heating program presented in Table 3 for 8 reaction vessels made of PFA using $2 \mathrm{~mL}$ of $\mathrm{HNO}_{3}$ and $1 \mathrm{~mL}$ of $\mathrm{H}_{2} \mathrm{O}_{2}$, both concentrated, for a mass of $0.250 \mathrm{~g}$ of sample. The digestates were diluted in $50 \mathrm{~mL}$ volumetric flasks with deionized water. The digestion was also carried out using a $1+1 \mathrm{v} / \mathrm{v}$ nitric acid solution, however in this case reagent volumes were $3 \mathrm{~mL}$ of acid solution and $2 \mathrm{~mL}$ of $\mathrm{H}_{2} \mathrm{O}_{2}$.

The determinations of barium in the digestates were performed using GF AAS and ICP OES. Selenium was also determined by GF AAS using a $1000 \mathrm{mg} \mathrm{L}^{-1} \mathrm{Pd}$ solution as chemical modifier. The heating programs (Table 1) were established using solutions containing 80 and $30 \mu \mathrm{g} \mathrm{L}^{-1}$ of $\mathrm{Ba}$ and $\mathrm{Se}$, respectively, in $0.014 \mathrm{~mol} \mathrm{~L}^{-1} \mathrm{HNO}_{3}$. ICP OES was used for determinations of $\mathrm{Ba}, \mathrm{P}$ and $\mathrm{S}$.

\section{Sequential extraction procedure based on solubility}

A sequential extraction procedure based on solubility was applied in 3 successive steps: $i$ - Extraction with hot water - $\left(60{ }^{\circ} \mathrm{C}\right.$ for $\left.30 \mathrm{~min}\right)$ promotes the separation of soluble compounds by adding $10 \mathrm{~mL}$ of deionized water to a mass of $0.5 \mathrm{~g}$ of sample. The mixture was agitated for about $2 \mathrm{~min}$, centrifuged for $10 \mathrm{~min}$ at 4,500 rpm $\left(\mathrm{g}=1.0 \times 10^{3}\right)$ and filtered. The subsequent steps are based on equilibrium reactions involving metathesis processes and subsequent dissolution in acid medium. The equilibrium global constants were calculated using equilibrium solubility product constants ${ }^{23}$ as it will be further discussed. $i i$ - Extraction in alkaline medium - The solid residue was treated with an excess of $\mathrm{Na}_{2} \mathrm{CO}_{3}(0.3 \mathrm{~g})$ and $5 \mathrm{~mL}$ of water with heating for $15 \mathrm{~min}$ at $60^{\circ} \mathrm{C}$. The resulting mixture was also agitated, centrifuged and filtered, as described for Step $i$. $i i i$ - Dissolution of the residue obtained in step $i i$ - The solid residue obtained in step $i i$ was dissolved in $10 \mathrm{~mL}$ of $0.7 \mathrm{~mol} \mathrm{~L}^{-1} \mathrm{HNO}_{3}$ followed by centrifugation and filtration. Consequently, the residues of the eventual formation of $\mathrm{BaCO}_{3}$ in step $i i$ were dissolved in acid medium.

Thermogravimetric analysis - Thermal analysis was carried out for residues obtained in all steps for one sample. The dry residues were submitted to a controlled heating program and the mass variation was recorded.

Sequential extraction: lipids, proteins and low molecular weight compounds

The lipids extraction was promoted by adding a mixture of chloroform-methanol $2: 1 \mathrm{v} / \mathrm{v}(10 \mathrm{~mL})$ to a mass of
$2.0 \mathrm{~g}$ of sample. After evaporating the solvent at room temperature, a mass of $0.250 \mathrm{~g}$ of the residual solid without lipids was microwave-assisted digested using the same heating program previously mentioned.

The extractions of proteins and low molecular weight (LMW) compounds were performed for sample aliquots without lipids after evaporating the solvent at room temperature. The classical Kjeldahl's method was applied for determining proteins contents.

The extraction of LMW compounds was also promoted by adding a volume of $40 \mathrm{~mL}$ of $0.4 \mathrm{~mol} \mathrm{~L}^{-1} \mathrm{HClO}_{4}$ to $2.0 \mathrm{~g}$ of dry sample. This mixture was kept in an ultrasonic bath for $2 \mathrm{~h}$ and water was changed periodically to avoid excessive heating. Additionally, only one vessel was used each time for avoiding effects caused by the heterogeneous distribution of ultrasound inside the bath.

The protein was extracted by adding $10 \mathrm{~mL}$ of $\mathrm{NaOH}$ $0.1 \mathrm{~mol} \mathrm{~L}^{-1}$ to $1.0 \mathrm{~g}$ of dry sample, followed by neutralization of the solution with $4 \mathrm{~mol} \mathrm{~L}^{-1} \mathrm{H}_{3} \mathrm{PO}_{4}$ and by precipitation with acetone addition under refrigeration for $30 \mathrm{~min}$. The precipitated proteins were digested in acid medium using microwave-assisted heating (see Table 3) after evaporating the solvent at room temperature.

The analysis of extracts obtained by sequential extractions was performed by ICP OES for Ba, P, S, and Se. The analytical solutions for calibration were prepared taking into account the different media for each extraction process.

\section{Results and Discussion}

\section{Determination of total concentrations}

Total concentrations were determined for samples cryogenically ground and microwave-assisted digested using nitric acid and hydrogen peroxide, both concentrated, owing to the high lipids contents of Brazil nuts. However, the use of a $7 \mathrm{~mol} \mathrm{~L}^{-1}$ nitric acid solution is also feasible by keeping the same heating program and sample mass but increasing the volume of the reagents. This strategy is advantageous because reduce the need of manipulation of concentrated acid and reduce the acid concentration of the digest. This latter aspect implies in a lower dilution of the digestates before measurements and improves the detection power. Additionally, the higher concentration of the solvent improves the coupling with microwave radiation. ${ }^{24}$

The determination of the total concentration of $\mathrm{Ba}$ in the digestates of Brazil nuts was performed by GF AAS and also by ICP OES for evaluating the accuracy of measurements. Results are shown in Table 4 and it may be seen that they are in agreement with previous literature 
Table 4. Barium concentrations in Brazil nuts determined by GF AAS and ICP OES

\begin{tabular}{lcc}
\hline Sample & \multicolumn{2}{c}{${\mathrm{Ba}\left(\mathrm{mg} \mathrm{kg}^{-1 *}\right)}^{$\cline { 2 - 3 }$}$} \\
\cline { 2 - 3 } & GF AAS & ICP OES \\
\hline 1 & $1769 \pm 43$ & $1868 \pm 7$ \\
3 & $2084 \pm 25$ & $2067 \pm 80$ \\
4 & $893 \pm 7$ & $905 \pm 8$ \\
5 & $860 \pm 15$ & $888 \pm 38$ \\
\hline
\end{tabular}

$*$ average \pm standard deviation, $\mathrm{n}=3$

data, since the barium concentration in Brazil nuts can be as high as 4,000 $\mathrm{mg} \mathrm{kg}^{-1} .{ }^{20}$ According to a paired $t$-test all results were in agreement at a $95 \%$ confidence level.

Barium concentrations determined by GF AAS varied from 860 to $2084 \mathrm{mg} \mathrm{kg}^{-1}$. The relative standard deviations were always lower than $3.1 \%$. Barium was also determined by ICP OES using the most sensitive ionic line at $455.403 \mathrm{~nm}$. Barium concentrations varied from 888 to $2067 \mathrm{mg} \mathrm{kg}^{-1}$.

The determination of the total concentrations of Se was performed by GF AAS using Pd as chemical modifier for thermal stabilization of the analyte during the ashing step. $^{25}$

As expected, the contents of selenium in Brazil nuts samples were greater than those typically found in staple foods. Selenium contents varied from 6.3 to $41.6 \mathrm{mg} \mathrm{kg}^{-1}$ (Table 5). According to Chang et al. ${ }^{19}$ the total concentration of selenium in Brazil nuts varied from 0.20 to $253 \mathrm{mg} \mathrm{kg}^{-1}$ depending on the source.

Table 5. Total concentrations of phosphorus, selenium and sulfur determined in Brazil nuts

\begin{tabular}{lccc}
\hline Sample & GF AAS & \multicolumn{2}{c}{ ICP OES } \\
\cline { 2 - 4 } & $\mathrm{Se}\left(\mathrm{mg} \mathrm{kg}^{-1 *}\right)$ & $\mathrm{S}\left(\mathrm{mg} \mathrm{kg}^{-1} *\right)$ & $\mathrm{P}\left(\mathrm{mg} \mathrm{kg}^{-1 *}\right)$ \\
\hline 1 & $8.50 \pm 0.55$ & $3512 \pm 14$ & $16618 \pm 87$ \\
2 & $12.3 \pm 0.3$ & $2964 \pm 132$ & $14513 \pm 573$ \\
3 & $8.40 \pm 0.72$ & $2651 \pm 14$ & $16445 \pm 78$ \\
4 & $41.6 \pm 0.3$ & $4266 \pm 91$ & $20577 \pm 735$ \\
5 & $6.30 \pm 0.34$ & $3018 \pm 51$ & $15691 \pm 151$ \\
\hline
\end{tabular}

* average \pm standard deviation, $\mathrm{n}=3$

Brazil nuts contain high sulfur concentration, present mainly in proteins in the form of methionine and cysteine, which contribute for its value as a functional food. ${ }^{14}$ Total concentrations of sulfur and phosphorus were determined by ICP OES (Table 5).

The high amounts of phosphorus, selenium and sulfur in Brazil nuts indicate that these elements in their anionic forms can combine with barium generating the respective compounds. Therefore, it may be supposed that the chemical forms of barium in Brazil nuts may be phosphate, sulfate or selenate salts. These species do not present toxicity due to its low solubility in water. ${ }^{18}$ Further experiments dealing with fractionation of chemical forms will be performed for evaluating this hypothesis.

\section{Fractionation of barium based on solubility}

The fractionation of barium compounds based on their solubility was carried out according to a three step sequential extraction. The first extraction was made with water, the second one with an alkaline solution and finally the solid residue was dissolved in acid medium. Analytes in all extracts were determined by ICP OES. Results for all fractions are shown in Table 6.

The separation of soluble compounds (fraction 1) was made by adding water to the sample and the residue 1 was obtained. This fraction contained a small concentration of barium, confirming that barium is present in Brazil nuts as an insoluble compound.

The addition of excess of sodium carbonate solution to the residue 1 promotes the conversion of insoluble compounds to barium carbonate (Scheme 1). It means that the equilibria are displaced towards the formation of respective salts. Barium carbonate has a low solubility $\left(\mathrm{K}_{\mathrm{s}}=2.69 \times 10^{-9}\right)$. However, this salt is easily dissolved in acid medium. The reaction between carbonate and acid promotes the formation of carbonic acid, liberating ions barium in solution. Carbonic acid is easily converted in acid medium to carbon dioxide. Consequently, after adding sodium carbonate to residue 1 it was promoted the conversion of the possible salts of barium to barium carbonate, forming a second residue and liberating ions selenate and/or sulfate in solution (fraction 2). Afterwards, barium precipitated as barium carbonate in the residue 2 was dissolved in acid medium (fraction 3). The chemical equations are presented in Scheme 1.

The equilibrium global constants were calculated using the solubility constants of the species leading to the values of 0.58 and 12.9 for the reactions between sodium carbonate with barium selenate and sodium carbonate with barium sulfate, respectively. These equilibrium global constants indicate that these reactions may occur spontaneously and the reaction with barium sulfate would be more likely because of the equilibrium constant value. However, other factors must be considered, such as the concentrations of the different fractions in the sample. Because of the high total concentration of phosphorus, it would be also reasonable to assume that barium phosphate also could represent one 
Table 6. Barium, sulfur and selenium concentrations in Brazil nuts for fractionation based on solubility

\begin{tabular}{|c|c|c|c|c|c|}
\hline Element & Sample & Fraction 1 & Fraction 2 & Fraction 3 & Total \\
\hline \multirow[t]{5}{*}{$\mathrm{Ba}\left(\mathrm{mg} \mathrm{kg}^{-1 *}\right)$} & 1 & $15.0 \pm 0.3$ & $199 \pm 20$ & $895 \pm 26$ & $1109 \pm 33$ \\
\hline & 2 & $39 \pm 1$ & $127 \pm 7$ & $1757 \pm 22$ & $1923 \pm 23$ \\
\hline & 3 & $18 \pm 1$ & $45.8 \pm 0.6$ & $571 \pm 32$ & $635 \pm 32$ \\
\hline & 4 & $17 \pm 1$ & $61.9 \pm 1.5$ & $551 \pm 7$ & $630 \pm 7$ \\
\hline & 5 & $32 \pm 2$ & $126 \pm 10$ & $1520 \pm 223$ & $1678 \pm 223$ \\
\hline \multirow[t]{5}{*}{$\mathrm{S}\left(\mathrm{mg} \mathrm{kg}^{-1 *}\right)$} & 1 & $1872 \pm 157$ & $619 \pm 24$ & $50 \pm 6$ & $2760 \pm 159$ \\
\hline & 2 & $1921 \pm 89$ & $377 \pm 1$ & $21 \pm 1$ & $2319 \pm 89$ \\
\hline & 3 & $1574 \pm 39$ & $396 \pm 17$ & $9 \pm 1$ & $1979 \pm 43$ \\
\hline & 4 & $2600 \pm 17$ & $335 \pm 2$ & $34 \pm 6$ & $2969 \pm 18$ \\
\hline & 5 & $1430 \pm 27$ & $520 \pm 30$ & $39 \pm 3$ & $1989 \pm 40$ \\
\hline \multirow[t]{5}{*}{$\operatorname{Se}\left(\mathrm{mg} \mathrm{kg}^{-1 *}\right)$} & 1 & $3.33 \pm 0.10$ & $0.90 \pm 0.10$ & $1.90 \pm 0.20$ & $6.90 \pm 0.24$ \\
\hline & 2 & $9.82 \pm 0.60$ & $2.96 \pm 0.08$ & $1.56 \pm 0.08$ & $14.3 \pm 0.6$ \\
\hline & 3 & $3.92 \pm 0.05$ & $0.99 \pm 0.10$ & $2.44 \pm 0.10$ & $7.35 \pm 0.15$ \\
\hline & 4 & $30.8 \pm 2.2$ & $1.93 \pm 0.15$ & $2.76 \pm 0.15$ & $35.5 \pm 2.2$ \\
\hline & 5 & $0.63 \pm 0.09$ & $1.32 \pm 0.12$ & $1.72 \pm 0.12$ & $3.67 \pm 0.19$ \\
\hline
\end{tabular}

* average \pm standard deviation, $\mathrm{n}=3$

of the possible chemical forms, since this salt is extremely insoluble $\left(\mathrm{K}_{\mathrm{s}}=6.03 \times 10^{-39}\right)$. However, when calculating the equilibrium global constant $\left(\mathrm{K}=3.09 \times 10^{-13}\right)$ this hypothesis was discarded. ${ }^{23}$

As previously mentioned, ICP OES calibration was made considering the medium of each fraction for preparing the analytical reference solutions. For instance, fraction 2 was quantified by comparison with blank and analytical solutions prepared in sodium carbonate for correcting interference effects caused by sodium. It is known that easily ionized elements may modify the intensities of the emission lines of the analyte. ${ }^{26}$ Barium determination was compromised when this salt was not added to the analytical reference solutions.

\section{Water Extraction $\rightarrow$ FRACTION $1 \rightarrow$ Residue 1}

\section{Alkaline Extraction $\rightarrow$ FRACTION $2 \rightarrow$ Residue 2}

$$
\begin{gathered}
\mathrm{BaSO}_{4(\mathrm{~s})}+\mathrm{Na}_{2} \mathrm{CO}_{3(\mathrm{~s})} \leftrightarrows \mathrm{BaCO}_{3(\mathrm{~s})}+2 \mathrm{Na}_{(\mathrm{aq})}^{+}+\mathrm{SO}_{4}^{2-}(\mathrm{aq}) \\
\mathrm{BaSeO}_{4(\mathrm{~s})}+\mathrm{Na}_{2} \mathrm{CO}_{3(\mathrm{~s})} \leftrightarrows \mathrm{BaCO}_{3(\mathrm{~s})}+2 \mathrm{Na}_{(\mathrm{aq})}^{+}+\mathrm{SeO}_{4}^{2-}(\mathrm{aq})
\end{gathered}
$$

Dissolution in Acid Medium $\rightarrow$ FRACTION $3 \rightarrow$ Residue 3

$$
\mathrm{BaCO}_{3(\mathrm{~s})}+2 \mathrm{H}_{(\mathrm{aq})} \leftrightarrows \mathrm{Ba}^{2+}{ }_{(\mathrm{aq})}+\mathrm{CO}_{2(\mathrm{~g})}+\mathrm{H}_{2} \mathrm{O}
$$

Scheme 1. Fractionation processes and chemical equilibria based on solubility.
According to the chemical equilibria presented in Scheme 1 and based on the hypothesis formulated, it may be supposed that the concentrations of sulfur and selenium would be greater for fractions 1 and 2 and the barium concentration would be greater in fraction 3 . Results shown in Table 6 confirmed these suppositions. The lowest concentrations of barium were found in the soluble fraction and varied from 15 to $39 \mathrm{mg} \mathrm{kg}^{-1}$. Greatest values were determined for samples 2 and 5, 39 and $32 \mathrm{mg} \mathrm{kg}^{-1}$ respectively. These samples also presented the greatest total barium concentration in the digestates. However, the levels found in fraction 1 do not cause harmful implications to human health, since according to the World Health Organization the lethal dose for humans is around 3 to $4 \mathrm{~g}^{17}$. The greatest concentrations of sulfur and selenium in fraction 1 were observed for all samples, except in sample 5 which presented a low level of selenium.

The distribution of barium, sulfur and selenium in the three fractions obtained by sequential extraction based on solubility is shown in Figure 1 for sample 2. The distribution profiles obtained for other samples are similar to this one.

Residues obtained in each fractionation step were also analyzed by thermal analysis. Thermogravimetric curves for sample 1 and its residues are presented in Figure 2. Residues 1 and 3 presented curves similar to the sample, occurring total burning of the organic material at a temperature around $600{ }^{\circ} \mathrm{C}$. A significant alteration only occurred for residue 2 and it may be seen that its profile is relatively similar to that obtained for pure $\mathrm{BaCO}_{3}$, showing around $20 \%$ of 
mass loss between 900 and $1100{ }^{\circ} \mathrm{C}$. This result confirms the hypothesis that barium is precipitated in fraction 2 as barium carbonate, as supposed by the metathesis process (Scheme 1). This insoluble form confirms the unavailability of barium in Brazil nuts.
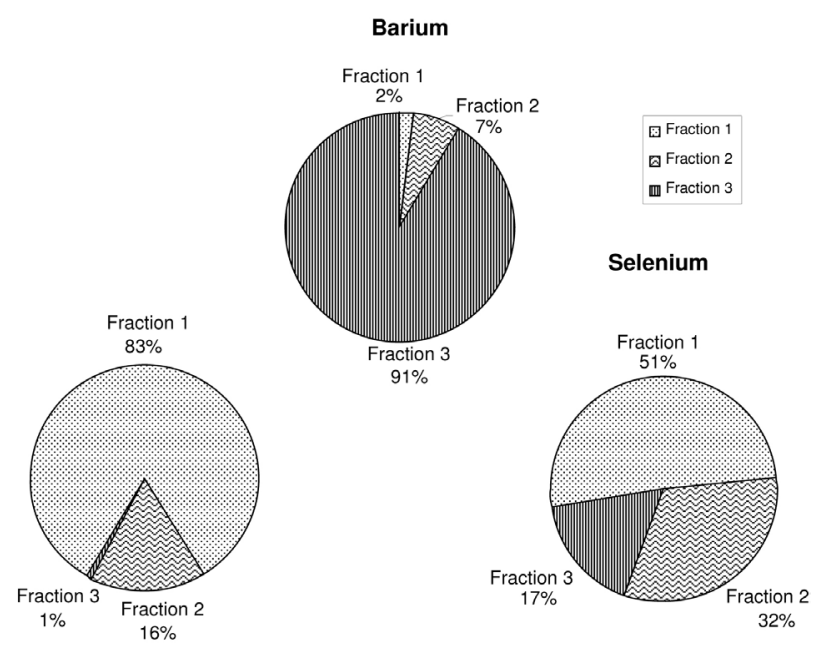

Figure 1. Fractionation based on solubility (sample 2).

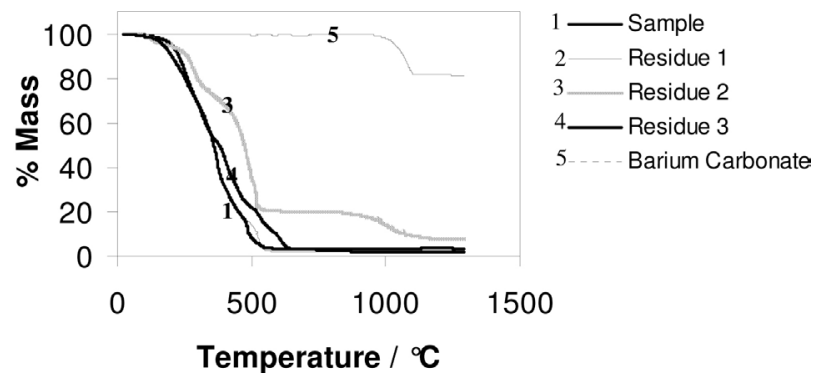

Figure 2. Thermogravimetric curves for sample, residues of fractionation based on solubility and pure barium carbonate.
Consequently, according to the fractionation based on solubility it was possible to verify the insolubility of the barium chemical compounds in Brazil nuts. Additionally, thermogravimetric experiments have contributed for confirming the presence of barium sulfate in Brazil nuts.

\section{Fractionation of barium based on chemical composition}

Further experiments were applied for evaluating the fractionation of barium based on its chemical composition. This strategy was applied for obtaining a better understanding of the barium distribution in Brazil nuts.

The extracts obtained in the lipids, proteins and LMW compounds were analyzed by ICP OES with axial configuration. It may be seen in Table 7 that the summation of the concentrations of the three different fractions is in good agreement with total concentrations determined by acid digestion.

Barium determination in LMW compounds was made employing the $233.527 \mathrm{~nm}$ line, which is less sensitive than the $455.403 \mathrm{~nm}$ line used for the other fractions in ICP OES measurements. This later line was unsuitable for LMW fraction due to the high barium concentration in this fraction.

The lipids extraction was carried out using chloroform / methanol 2:1 v/v mixture that led to around $65 \% \mathrm{~m} / \mathrm{m}$ of lipids.

After the separation of the lipids, the other fractions containing proteins and LMW compounds were extracted. The Kjeldahl's method indicated a content of around $15 \% \mathrm{~m} / \mathrm{m}$ of proteins.

Table 7. Barium, sulfur and selenium concentrations* in Brazil nuts for fractions separated based on chemical composition

\begin{tabular}{|c|c|c|c|c|c|}
\hline Element & Sample & Lipids & Proteins & LMW & Total \\
\hline \multirow[t]{5}{*}{$\mathrm{Ba}\left(\mathrm{mg} \mathrm{kg}^{-1 *}\right)$} & 1 & $54.3 \pm 0.1$ & $66.5 \pm 1.7$ & $1641 \pm 5$ & $1762 \pm 5$ \\
\hline & 2 & $39.7 \pm 1.1$ & $207 \pm 9$ & $1606 \pm 23$ & $1853 \pm 25$ \\
\hline & 3 & $30.7 \pm 0.9$ & $133 \pm 6$ & $807 \pm 3$ & $971 \pm 7$ \\
\hline & 4 & $5.57 \pm 0.24$ & $17.6 \pm 0.9$ & $778 \pm 35$ & $801 \pm 35$ \\
\hline & 5 & $0.14 \pm 0.03$ & $18.60 \pm 0.01$ & $1786 \pm 7$ & $1805 \pm 7$ \\
\hline \multirow[t]{5}{*}{$\mathrm{S}\left(\mathrm{mg} \mathrm{kg}^{-1 *}\right)$} & 1 & $19.10 \pm 0.05$ & $2814 \pm 154$ & $395 \pm 6$ & $3228 \pm 154$ \\
\hline & 2 & $13.5 \pm 0.9$ & $2265 \pm 85$ & $380 \pm 10$ & $2659 \pm 86$ \\
\hline & 3 & $17.6 \pm 0.7$ & $1911 \pm 125$ & $756 \pm 7$ & $2685 \pm 125$ \\
\hline & 4 & $12.9 \pm 0.8$ & $2952 \pm 98$ & $349 \pm 2$ & $3314 \pm 98$ \\
\hline & 5 & $12.1 \pm 0.7$ & $2794 \pm 127$ & $363 \pm 3$ & $3169 \pm 127$ \\
\hline \multirow[t]{5}{*}{$\mathrm{Se}\left(\mathrm{mg} \mathrm{kg}^{-1 *}\right)$} & 1 & $<\mathrm{LOD}$ & $12.9 \pm 0.7$ & $0.94 \pm 0.03$ & $13.8 \pm 0.7$ \\
\hline & 2 & $<$ LOD & $9.8 \pm 0.9$ & $2.65 \pm 0.24$ & $12.5 \pm 0.9$ \\
\hline & 3 & $<$ LOD & $12.4 \pm 0.4$ & $1.90 \pm 0.08$ & $14.3 \pm 0.4$ \\
\hline & 4 & $<\mathrm{LOD}$ & $37.0 \pm 3.1$ & $1.84 \pm 0.15$ & $38.8 \pm 3.1$ \\
\hline & 5 & $<\mathrm{LOD}$ & $6.7 \pm 0.8$ & $0.14 \pm 0.01$ & $6.84 \pm 0.80$ \\
\hline
\end{tabular}

* average \pm standard deviation, $\mathrm{n}=3 ; * *<\mathrm{LOD}$ - lower than the limit of detection 
The proteins were dissolved and separated of the organic matrix due to its high solubility in alkaline medium. After neutralization of the solution containing proteins, the precipitation was promoted by adding acetone at low temperatures.

A careful control of $\mathrm{pH}$ and temperature was necessary after the separation of the proteins for avoiding their denaturation. Therefore, processes were carried out at low temperature and $\mathrm{pH}$ was adjusted to 7 by adding phosphoric acid.

The LMW compounds were extracted using perchloric acid added to Brazil nuts without lipids. It is also known that alkaline medium promotes the extraction of compounds with high molecular mass. ${ }^{1}$

The ultrasound-assisted extraction of LMW compounds was developed by controlling critical parameters, such as the position of the reaction vessel in the ultrasound bath and the temperature of the water. Vessels were kept in the central position of the bath for all samples and water was periodically changed to keep the temperature around $25-30{ }^{\circ} \mathrm{C}$. These conditions are compatible with those established by Nascentes et al. ${ }^{27}$

As expected, sulfur and selenium are mainly contained in the protein fraction. Previous study has shown that selenium is covalently bond to proteins by methionine and cysteine amino acids. ${ }^{28}$ Sulfur is present in these amino acids. On the other hand, selenium was not detected in the lipids fraction as previously pointed out. ${ }^{7}$

The concentrations of sulfur and selenium in the protein fraction are similar to those determined in the water soluble fraction. Methionine is apolar and presents low solubility in water. However, heating may cause partial denaturation of the proteins. Thus, it may be supposed that sulfur and selenium in proteins were also extracted by water. Sulfur and selenium are not only incorporated in proteins, since LMW compounds fraction also presented considerable concentrations of both. The possibility of association with barium in this fraction would be inferred.

The barium concentrations in LMW compounds fraction varied from 778 to $1786 \mathrm{mg} \mathrm{kg}^{-1}$. However, lipids fraction contained low concentrations of barium. The greatest contents of $\mathrm{Ba}$ in LMW fraction contribute to reinforce the hypothesis that barium is mainly present in sulfate or selenate forms. Barium concentrations in the protein fraction varied from 17.6 to $207 \mathrm{mg} \mathrm{kg}^{-1}$. The metal presence can influence the activities of proteins owing to the possible interactions between them. The affinity of proteins for metal ions is exploited in biological systems for performing important functions to the organisms, such as catalysis, structural support and transport. It is known that transition metal ions, such as $\mathrm{Cu}(\mathrm{II}), \mathrm{Ni}(\mathrm{II}), \mathrm{Zn}(\mathrm{II})$ and $\mathrm{Co}(\mathrm{II})$, can coordinate with amino acids, such as the hystidine, cysteine and tryptophan, through electron donor groups in the lateral chains of these amino acids. ${ }^{29}$ However, there is limited information about barium interactions with proteins.

Barium concentrations in the lipids fraction was determined by ICP OES and varied from 0.14 to $54.3 \mathrm{mg} \mathrm{kg}^{-1}$. Some previous studies evaluated the influence of alkaline earth ions in phospholipid monolayers. ${ }^{30-31}$ McLoughlin et al..$^{30}$ established that $\mathrm{Ca}$ (II) plays a greater effect in the interaction between DNA and phospholipids than $\mathrm{Mg}(\mathrm{II})$ or $\mathrm{Ba}(\mathrm{II})$. These effects generally are associated to the interactions with water, molar volume and energy of hydration (enthalpy and entropy).

Sulfur and selenium presented similar behavior, with greater concentrations in the proteins fraction and lower concentration in the lipids fraction. The major fraction of barium is present in LMW compounds. The proteins fraction contained around $11 \%$ of this element. Figure 3 shows the distribution of barium, sulfur and selenium in the lipids, proteins and LMW compounds fractions for sample 2. Similar profiles were obtained for other samples.

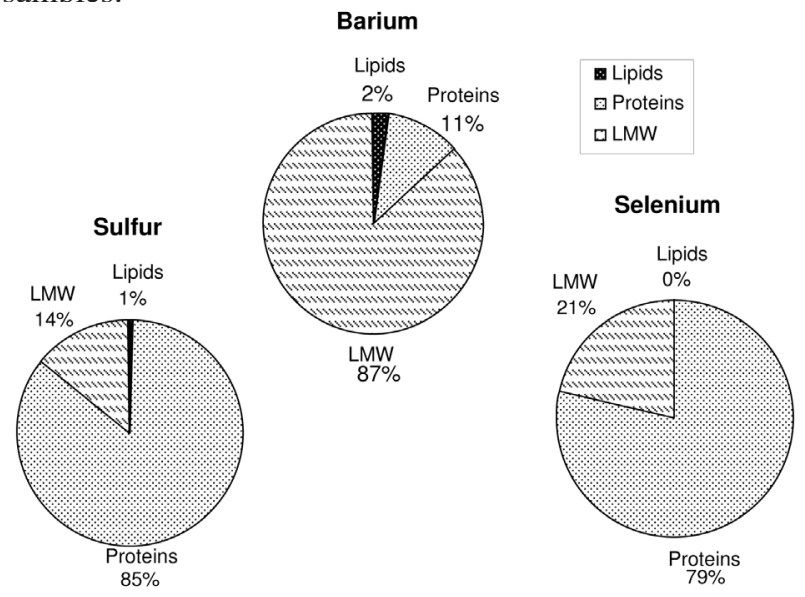

Figure 3. Fractionation based on chemical composition (sample 2).

\section{Stoichiometric calculations}

Chemical processes can be rationalized taking into account the stoichiometry of the reactions. Thus, stoichiometric calculations were applied for barium, sulfur and selenium concentrations determined in LMW compounds fraction using the chemical solubility equilibria for barium sulfate and barium selenate.

A direct relation was observed between $\mathrm{Ba}$ and $\mathrm{S}$ in LMW compounds fraction for some samples. For instance, for sample 2 the supposed formation of barium sulfate from 
a mass of barium of $1.606 \mathrm{~g}$ contained in LMW compounds requires $0.375 \mathrm{~g}$ of sulfur. The experimentally determined amount of sulfur in this fraction was $0.380 \mathrm{~g}$, which is in good agreement with barium sulfate formation.

Table 8 presents the extrapolated masses of barium and sulfur in $1.0 \mathrm{~kg}$ of LMW compounds, as well as the masses needed of sulfur to form barium sulfate. Samples 1, 2 and 4 presented experimental masses close to the calculated masses required for formation of barium sulfate. The determined mass of sulfur for sample 3 is greater than the needed mass to form barium sulfate. This sample also presented lower sulfur concentration in proteins fraction compared to the other samples, however sulfur concentration in LMW fraction was greater. Only the sample 5 presented a sulfur concentration $14 \%$ below of that required for formation of barium sulfate, but this difference is acceptable considering all successive experimental steps.

Table 8. Masses of barium and sulfur determined in LMW compounds fraction and stoichiometric masses of sulfur necessary to react with barium to form barium sulfate

\begin{tabular}{lccc}
\hline Sample & $\begin{array}{c}\text { Ba Mass (g) } \\
\text { Determined }\end{array}$ & $\begin{array}{c}\text { S Mass (g) } \\
\text { Determined }\end{array}$ & $\begin{array}{c}\text { S Mass (g) } \\
\text { Stoichiometric }\end{array}$ \\
\hline 1 & 1.64 & 0.40 & 0.38 \\
2 & 1.61 & 0.38 & 0.37 \\
3 & 0.80 & 0.76 & 0.19 \\
4 & 0.80 & 0.35 & 0.19 \\
5 & 1.79 & 0.36 & 0.42 \\
\hline
\end{tabular}

Consequently, it may be concluded that these data and stoichiometric calculations also supports the hypothesis that barium is mainly present in Brazil nuts as barium sulfate.

\section{Conclusions}

Sequential extractions procedures have demonstrated that barium is mainly present in Brazil nuts as insoluble compounds, particularly barium sulfate or even barium selenate. The presence of this element as an insoluble form was expected taking into account that Brazil nuts, in spite of its high concentrations of barium, did not have any toxic effects to humans. Thermogravimetric experiments for residues obtained in successive extraction steps confirmed the hypothesis about the presence of barium sulfate and formation of barium carbonate in a sodium carbonate solution medium. The presence of sulfur and selenium in the LMW compounds fraction also indicated the possibility of association with barium in this fraction. It was also demonstrated that barium occurs in high concentrations in the LMW compounds fraction. The hypothesis was also confirmed by stoichiometric calculations and equilibrium constants. Consequently, it may be inferred that the main barium form in Brazil nuts is barium sulfate. Therefore, as supposed, although barium is present in high concentrations in Brazil nuts, it did not have any implications to the human health due to its unavailability.

\section{Acknowledgements}

The authors are grateful to Fundação de Amparo à Pesquisa do Estado de São Paulo (FAPESP), Conselho Nacional de Desenvolvimento Científico e Tecnológico (CNPq) and Coordenadoria de Aperfeiçoamento de Pessoal de Nível Superior (CAPES) for research funds and fellowships.

\section{References}

1. Kannamkumarath, S. S.; Wuilloud, R. G.; Caruso, J. A.; J. Agric. Food Chem. 2004, 52, 5773.

2. Fairweather-Tait, S. J.; Fresenius' J. Anal. Chem. 1999, 363, 536.

3. Cornelis, R.; Caruso, J. A.; Crews, H.; Heumann, K.; Eds., Handbook of Elemental Speciation: Techniques and Methodology. John Wiley \& Sons: Chichester, 2003.

4. Buldini, P. L.; Ricci, L.; Sharma, J. L.; J. Cromatogr. A 2002 , $975,47$.

5. Welz, B.; Sperling, M.; Atomic Absorption Spectrometry. $3^{\text {rd }}$ ed., VCH Publisher: Weinheim, 1999.

6. Vandecasteele, C.; Block, C. B.; Modern Methods for Trace Element Determination. John Wiley \& Sons: Chichester, 1993.

7. Kannamkumarath, S. S.; Wrobel, K.; Caruso, J. A.; Anal. Bioanal. Chem. 2002, 373, 454.

8. Müller, C. H.; Figueiredo, F. J. C.; Kato, A. K.; Carvalho, J. E. U.; Stein, R. L. B.; Silva, A. B.; A Cultura da Castanha-doBrasil. Embrapa SPI: Brasília, 1995.

9. Locatelli, M.; Vieira, A. H.; Gama, M. M. B.; Ferreira, M. G. R.; Martins, E. P.; Filho; E. P. S.; Souza, V. F.; Macedo, R. S.; Cultivo da Castanha-do-Brasil em Rondônia. Embrapa: Rondônia, 2005.

10. Harri, L.; Árvores Brasileiras: Manual de Identificação e Cultivo de Plantas Arbóreas do Brasil. $2^{\text {nd }}$ ed., Plantarum: Nova Odessa, 1998, vol. 1.

11. Ip, C.; Lisk, D. J.; Nutr. Cancer 1994, 21, 203.

12. Dernovics, M.; Giusti, P.; Lobinski, R.; J. Anal. At. Spectrom. 2007, 22, 41 .

13. Moreno, F. J.; Jenkis, J. A.; Mellon, F. A.; Rigby, N. M.; Robertson, J. A.; Wellner, N.; Mills, E. N. C.; Biochim. Biophys. Acta, 2004, 1698, 175.

14. Sun, S. S. M.; Altenbach, S. B.; Leung, F. W.; Eur. J. Biochem. 
1987, 162, 477.

15. Kannamkumarath, S. S.; Wrobel, K.; Wuilloud, R. G.; Talanta 2005, 66, 153 .

16. Berman, E.; Toxic Metals and Their Analysis. Heyden \& Son: Londres, 1980.

17. World Health Organization (WHO). International Program on Chemical Safety (IPCS), Concise International Chemical Assessment Document 33. Barium and Barium Compounds. Geneva, 2001.

18. Agency for Toxic Substances and Disease Registry (ATSDR). Public Health Service, US Department of Health and Human Services. Toxicological Profiles for Barium. Atlanta, 1992.

19. Chang, J. C.; Gutenmann, W. H.; Reid, C. M.; Lisk, D. J.; Chemosphere 1995, 30, 801.

20. Stoewsand, G. S.; Anderson, J. L.; Rutzke, M.; Lisk, D. J.; Nutr. Rep. Int. 1988, 38, 259.

21. Tubino, M.; Simoni, J. A.; Quim. Nova 2007, 30, 505.

22. Smith, K. A.; Plant Soil 1971, 34, 369.

23. Martell, A.; Smith, R.; Montekaitis, R. J.; NIST Critically Selected Stability Constants in NIST Standard Reference
Database. Electronic program version 4.0, 1998.

24. Trevizan, L. C.; Donati, G. L.; Nogueira, A. R. A.; Nóbrega, J. A.; Microwave-assisted Procedures for Sample Preparation: Recent Developments. In: Arruda, M. A. Z.; Ed.; Trends in Sample Preparation. Nova Science: New York, 2007.

25. Aleixo, P. C.; Nóbrega, J. A.; Food Chem. 2003, 83, 457.

26. O’Hanlon, K.; Ebdon, L.; Foulkes, M.; J. Anal. At. Spectrom. 1997, 12, 329.

27. Nascentes, C. C.; Korn, M.; Souza, C. S.; Arruda, M. A. Z.; J. Braz. Chem. Soc. 2001, 12, 57.

28. Chunhieng, T.; Pétritis, K.; Elfakir, C.; Brochier, J.; Goli, T.; Montet, D.; J. Agric. Food Chem. 2004, 52, 4318.

29. Karmali, A.; Bol. Biotecnol. 2000, 67, 2.

30. McLoughlin, D.; Dias, R.; Lindman, B.; Cardenas, M.; Nylander, T.; Dawson, K.; Miguel, M.; Langevin, D.; Langmuir 2005, 21, 1900.

31. Walter, A.; Siegel, D. P.; Biochemistry, 1993, 32, 3271.

Received: January 16, 2009 Web Release Date: April 30, 2009

FAPESP helped in meeting the publication costs of this article. 